\title{
Mixed-Methods Assessment of a Mentoring Program
}

This is an accepted manuscript of an article published online on 9/16/19

by Taylor \& Francis in Journal of Library Administration

and is available at: https://www.tandfonline.com/doi/full/10.1080/01930826.2019.1661745

\begin{abstract}
A continuous cycle of mixed-methods assessment contributes to the success of a mentoring program, as shown in this case study from a large academic library. Assessment instruments include the Mentoring Competencies Assessment, the Fear of Negative Evaluation Scale, a satisfaction survey and a focus group. Assessment results reveal that the mentoring program is meeting its goals of contributing to the professional development of protégés, improving mentor competencies, increasing confidence of participants, and expanding participation in the program.
\end{abstract}

Keywords: mentoring, assessment, academic libraries

\author{
Authors \\ Karen Harker, Collection Assessment Librarian, University of North Texas Libraries, 1155 \\ Union Circle \#305190, Denton, Texas 76203. E-mail: Karen.Harker@unt.edu \\ Erin O'Toole, Science Reference Librarian, University of North Texas Libraries, 1155 Union \\ Circle \#305190, Denton, Texas 76203. E-mail: Erin.O’Toole@unt.edu \\ Setareh Keshmiripour, Head of Access Services, University of North Texas Libraries, 1155 \\ Union Circle \#305190, Denton, Texas 76203. E-mail: Setareh.Keshmiripour@unt.edu \\ Marcia McIntosh, Digital Production Librarian, University of North Texas Libraries, 1155 Union \\ Circle \#305190, Denton, Texas 76203. E-mail: Marcia.McIntosh@unt.edu \\ Catherine Sassen, Principal Cataloger, University of North Texas Libraries, 1155 Union Circle \\ \#305190, Denton, Texas 76203. E-mail: Catherine.Sassen@unt.edu \\ Running head \\ Mixed-Methods Assessment
}




\section{Mixed-Methods Assessment of a Mentoring Program}

\section{Introduction}

Formal mentoring programs are associated with significant benefits for protégés, mentors and their institutions, according to a review of research studies by Johnson (2016). Benefits for protégés include professional skill development, scholarly productivity, networking, professional confidence, career advancement, improved job satisfaction, and reduced stress. In addition, mentors benefit through the satisfaction of helping others succeed, personal fulfillment, professional rejuvenation, networking, and motivation to stay up to date with scholarship. Furthermore, benefits for educational institutions include greater success in retaining faculty and a reputation for developing talent.

A mentoring program can ensure its relevance, effectiveness and sustainability by conducting assessments. The evaluation of a mentoring program is needed for several reasons (Lunsford, 2016). First, assessment provides unbiased information about changes needed in the program. Additionally, assessment results can identify how resources should be directed to improve the program. Furthermore, assessment evidence can be shared with current and potential stakeholders to stress the success of the program. Sharing assessment information with administrators may contribute to program funding and time allowed for participants. Sharing assessment results with potential participants may encourage them to join the program. Assessment also is needed to track the implementation of the mentoring program's plans and goals (Bland, Taylor, Shollen, Weber-Main, \& Mulcahy, 2011). For best results, formal 
assessments should be administered in a continuous cycle to both protégés and mentors (Law et al., 2014).

Satisfaction surveys are used to assess many faculty development programs (Hines, 2009). Although this measure could be used to address areas of dissatisfaction, it is limited in its scope. Multiple measures and mixed methods are needed to determine the impact of a program on the participants' skills, abilities, and future careers.

\section{Literature review}

The authors investigated the topic of assessment of formal mentoring programs that support early-career academics as they begin to engage in scholarship and service and to develop into professionals. The analysis focused on the characteristics, rigor, and reproducibility of the assessments. The mentoring literature from both academic librarianship and higher education was included in the review because of the similarities between librarians and teaching faculty at institutions of higher education. Academic librarians and teaching faculty both work to achieve overarching goals of colleges and universities and frequently have overlapping responsibilities and privileges. Sassen and Wahl (2014) found in a survey of members of the Association of Research Libraries (ARL) that librarians hold faculty status at 54\% of the institutions and hybrid faculty status at another $15 \%$. The survey results also indicate a majority of the institutions with tenure-track librarians require publication for promotion. Mentoring for teaching faculty and its assessment can provide guidance for academic librarians when they are developing and assessing their own programs.

The researchers conducted searches of library and information science (LIS) and higher education literature in the following EBSCOhost databases: ERIC, Education Source, Library and Information Science Source, Professional Development Collection, and Library, Information 
Science \& Technology Abstracts. The search strategy for LIS literature focused on the assessment or evaluation of formal mentoring programs for librarians at universities or colleges, for the publication years 2010 through 2019. The other search sought publications about the assessment or evaluation of formal mentoring programs for teaching faculty, whether tenure or non-tenure track. The time range was narrower for the higher education search, 2015 through 2019, because publications on the topic are much more plentiful than in LIS literature. To keep the scope of the review manageable, the researchers included mentoring programs for scholarship, service, and general professionalism, which are the typical promotion requirements for academic librarians, and excluded mentoring solely for teaching, clinical activities, or leadership. Three review articles (Boeren et al., 2015; Fountain \& Newcomer, 2016; Lorenzetti \& Powelson, 2015) identified older publications, which were added to the review of LIS and higher education literature when they met the inclusion criteria.

\section{Assessment of Mentoring Programs in Academic Libraries}

Few academic libraries provide mentoring for early-career librarians and even fewer assess their mentoring programs. Of the librarians in Goodsett and Walsh's study (2015) who had a formal mentoring program, $100 \%$ responded that the mentoring program was not assessed. Lorenzetti and Powelson's review (2015) of mentoring literature paints a slightly better picture with 18 out of 40 identified case studies reporting assessment of a formal mentoring program. The current literature review revisits the 18 studies and extends to literature published between 2014 and 2019 about assessment of mentoring programs in academic libraries.

The majority of the case studies reviewed by Lorenzetti and Powelson (2015) describe quantitative assessment by the survey method. The coordinators of the mentoring programs were thorough in administering surveys to all participants, regardless of rank, tenure status, or role 
(mentor/protégé), in both dyad and peer mentoring programs. This is a strength of the surveys because measures of engagement and satisfaction of all participants are necessary for making improvements and winning administrative support for mentoring programs. A weakness of the survey instruments is the lack of testing for validity and reliability, which are characteristics valued in a rigorous survey method (Fowler, 2009). The most serious weakness in the preponderance of case studies is the failure to include the survey instrument itself, or even the survey questions. Cirasella and Smale (2011) and Sapon-White et al. (2004) did append the survey instruments, making it possible for the library assessment community to peer review the battery of questions and replicate the assessments.

Two case studies identified by Lorenzetti and Powelson (2015) describe qualitative assessments of mentoring programs: interviews and round table discussions (Bosch et al., 2010; Kuyper-Rushing, 2001). Qualitative methods have the potential advantage over a survey of revealing a deeper understanding of participants' perspectives and development over a course of a program. These case studies have a paucity of details about how the assessments were conducted, which makes peer review and replication of the methods problematic. For instance, Kuyper-Rushing (2001) reports facilitating multiple discussion groups, but the discussion questions are not provided in the case study. A more serious concern in both assessments is the lack of a safe space where participants could freely discuss their opinions. The coordinators of the mentoring programs, rather than an impartial party, facilitated the interviews (Bosch et al., 2010) and round table discussions (Kuyper-Rushing, 2001). Their presence may have had an impact on the participants' discussion, resulting in responses that may have been less than candid and complete. 
Ideally, assessment of a mentoring program should include both quantitative and qualitative methods, which can offset each other's strengths and limitations and provide triangulation (Clark \& Ivankova, 2016). The remaining four case studies that included assessment and were reviewed by Lorenzetti and Powelson (2015) achieve this balance by using mixed methods in assessing mentoring activities (Colley \& Thorson, 1990; Farmer et al., 2009; Ghouse \& Church-Duran, 2008; Sullivan et al., 2013). However, these assessments suffer from the same weaknesses described earlier. Surveys were the quantitative evaluation described in all four articles, but only one case study appended the instrument for peer review and replication (Farmer et al., 2009). The case studies fail to report the questions asked at group discussions and interviews, and most indicate the administrators of the mentoring programs conducted the interactions, rather than facilitators who had no investment in the programs.

The more recent articles identified are notable for how little they contribute to the academic library community's knowledge of how to do rigorous assessment of mentoring programs. The search for publications from 2014 to 2019 reveals no new case studies of mentoring programs including assessment. Two surveys of sizeable populations of individual librarians (Goodsett \& Walsh, 2015) and ARL libraries (Anaya et al., 2017) found few libraries assess the success of their mentoring programs. Research about library mentorship is evolving from case studies to large-scale surveys, but these recent studies do not include any questions about the assessment of mentoring programs (Harrington \& Marshall, 2014; Idoko et al. 2016; Nwankwo et al., 2017; Vilz \& Poremski, 2015).

\section{Assessment of Mentoring Programs in Higher Education}

A recent examination of literature from higher education on the topic of mentoring finds that numerous articles describe the activity, but few include results of mentoring program assessment 
(Boeren et al., 2015). The authors identify 23 studies with a majority of mixed method and qualitative assessments of mentoring programs and fewer quantitative studies. The most frequently applied quantitative method is the survey. Nearly all of the studies are based on a one-time assessment of programs, thus Boeren et al. recommend more longitudinal studies.

The current literature review confirms there are few published assessments of mentoring programs, but uncovers a different balance of mixed method and solely quantitative or qualitative method studies. Mixed method studies (Bean et al., 2014; Fox, 2012; Marcellino, 2011; Thomas et al., 2015) and qualitative studies (Bell \& Treleaven, 2011; Carney et al., 2016; Hubball et al., 2010) compose a minority of the mentoring assessments. Quantitative studies, employing one or more methods, are more prevalent (Bertram et al., 2015; Browning et al., 2014; Cofrancesco et al., 2018; Huenneke et al., 2017; Mayer et al., 2014; Minnick et al., 2018; Morrison et al., 2014; Sheridan et al., 2015; Slimmer, 2012; Varkey et al., 2012; Weaver, 2013). This finding suggests a shift toward quantitative assessment since 2014. The differing balance of methods in this review may be explained by the narrower time range selected for the literature search and use of different databases than in Boeren et al.'s study. However, the shift may be an actual response to demands for more quantitative assessment of formal mentoring programs

The survey continues to be one of the most commonly administered assessments, as also seen in Boeren et al.'s review (2015) and the mentoring literature of librarianship. All of the mixed methods studies employ surveys for assessment, some with both quantitative and qualitative elements (Bean et al., 2014; Fox 2012; Thomas et al., 2015). About half of the quantitative studies use a survey, alone or in addition to other quantitative tools. Researchers who report on a single administration of a survey, usually do so after the pilot year(s) of a mentoring program (Marcellino, 2011; Sheridan et al., 2015; Slimmer, 2012; Thomas, 2015; Varkey et al., 2012). In line with the 
goals of improving and sustaining programs, some coordinators of mentoring activities have increased the rigor of their assessment by conducting surveys on an annual basis (Bean et al., 2014; Bertram et al., 2015; Cofrancesco et al., 2018; Fox, 2012). Another strength among the surveys of faculty mentoring programs is the majority are given to both mentors and protégés, which contributes to improvement of a program and the continuing engagement of participants.

Two of the surveys are preferred models for assessment of mentoring because they have more rigorous characteristics. Mayer et al. (2014) gave participants in a peer mentoring group for women faculty a pre- and post-survey, which is preferable for measuring the impact of an intervention, compared to a single post-assessment. In addition, the survey queried participants about their academic skills, instead of satisfaction only. The instrument is included in the article, allowing for peer review and reproducibility. Bean et al. (2014) share the survey instrument they administered, which was examined for validity. While they did not have a panel to test content validity, the authors determined the instrument had face validity and considered content validity in the instrument's development. Finally, this assessment team also provided confidentiality and privacy to respondents by having a student assistant remove identifying data before they analyzed the quantitative and qualitative responses.

The other dominant research method applied in both mixed methods and quantitative studies is data analysis of tenure and promotion records. The data analysis usually focuses on the curriculum vitae of protégés and tallies the number of manuscripts submitted and published, grants proposed and awarded, presentations, and other scholarly activities after participation in the mentoring program (Bertram et al., 2015; Browning et al., 2014; Cofrancesco et al., 2018; Huenneke et al., 2017; Marcellino, 2011; Mayer et al., 2014; Minnick et al., 2018; Varkey et al., 2012; Weaver et al., 2013). Three studies analyze tenure and promotion data to determine years to 
promotion (Morrison et al., 2014), number of successful tenure applications (Bertram et al., 2015; Huenneke et al., 2017), and retention of the protégés (Huenneke et al., 2017). Data analysis is not an assessment method among the LIS articles identified by Lorenzetti and Powelson (2015) or the current authors, but three studies did administer surveys asking librarians to self-report scholarly outcomes from the mentoring program (Farmer et al., 2009; Miller \& Benefiel, 1998; Sullivan et al., 2013).

A weakness of many of the data analysis studies from the higher education literature is the lack of details about how the analyses are conducted, e.g., which activities count as scholarly, how frequently the analyses are conducted, and whether there is a control group to compare with the protégés in a program. The absence of this information makes it challenging to review and reproduce the studies. The emphasis on data analysis of tenure and promotion records in the higher education literature, absent in the LIS literature, is not surprising considering the higher scholarly output usually expected of teaching faculty compared to library faculty. Additionally, some faculty programs are accountable to a funding body with external stakeholders and need to provide evidence of scholarly outcomes (Huenneke et al., 2017; Cofrancesco, 2018), a situation not found in the LIS literature. This assessment approach, with modifications, may be a useful tool for mentoring programs in academic libraries that need to demonstrate long-term outcomes.

The qualitative assessment methods applied most frequently in the higher education studies of faculty mentoring are interviews with protégés (Carney et al., 2016; Thomas et al., 2015) or both mentors and protégés (Hubball et al., 2010), and focus groups (Bell \& Treleaven, 2011; Hubball et al., 2010; Marcellino, 2011). None of the interview questions are shared in the publications, which means they are unavailable for peer review or re-use. The study by Carney et al. stands out for having a faculty member outside of the mentoring program conduct the protégé 
interviews, which would encourage more candid responses. Bell \& Treleaven's study (2011) is the only assessment by focus group that provides the facilitator's questions. None of the focus group studies mention conducting the groups in a manner to provide anonymity to the participants.

The reported assessments of mentoring programs in LIS and higher education literature are limited in their rigor and availability for peer review and reproducibility. Only a handful of studies in each area are mixed methods studies, which enable a deeper understanding of the impact of a program on participants. Most survey instruments are not included in the publications and none have been fully tested for reliability and validity. Only two studies protect assessment participants with either a facilitator from outside the mentoring program or data processing that strips identifying information. This case study presents a model of mixed methods assessment that is rigorous and sustained, yet can be accomplished in the limited time available to academic librarians who are administering a mentoring program. The authors hope to contribute to the improved assessment of mentoring programs in academic libraries, and in higher education generally, with this study and its accompanying instruments.

\section{UNT Mentoring Program}

The subject of this case study is a mentoring program for librarians at the University of North Texas (UNT) Libraries in Denton, Texas. With over 35,000 students, UNT is the largest public university in the Dallas-Fort Worth area. UNT Libraries' cataloged holdings include over six million print and digital items housed in six facilities. The Libraries employ approximately 55 librarians. Although UNT librarians have faculty status, they do not have faculty rank or tenure. Nevertheless, they are eligible for service on the Faculty Senate and its committees. They also are eligible for research funds, development leaves, and faculty awards. 
UNT librarians are evaluated annually by administrators on their assigned duties. They also are evaluated annually by a peer review committee on their scholarship and service. Librarians must meet evaluation criteria in all three areas to achieve contract renewal and promotion. When the Libraries' evaluation criteria for scholarship became more rigorous in 2010 , various librarians expressed concern that their graduate education had not adequately prepared them to conduct original research. These concerns have been expressed by many other academic librarians in other institutions. For example, in a 2015 study of academic librarians, only $17 \%$ of 659 respondents indicated that they believed that their library and information science master's degree coursework sufficiently prepared them to conduct original research (Kennedy \& Brancolini, 2018).

A Career Development Program was created at UNT in 2010 to help librarians meet increased expectations in research and publication (Harker, O’Toole, \& Sassen, 2018). Although the Career Development Program provided five presentations a year on various professional development topics, it received continuing requests for one-on-one mentoring. The UNT Libraries' Mentoring Program was created in 2015 in response to these requests.

The Mentoring Program Workgroup administers the Mentoring Program. The Workgroup is composed of librarians of all ranks from various divisions of the Libraries. Workgroup members are appointed for staggered 2-year terms. The current officers include two co-chairs, an assessment officer, a mentorship coordinator, and a secretary. The Director of Library Administrative Services is an ex-officio member of the Workgroup. Current and former members of the Workgroup make up the authorship team of this article. 
The duties of the Mentoring Program Workgroup include managing the Mentoring Program, making recommendations for its budget, and addressing issues with mentoring partnerships and mentor training. The Workgroup also is responsible for assessing the Program and making changes in the program as needed.

The mission of the Mentoring Program is to support librarians to be successful in their careers. Potential protégés of the program include librarians who are new to the UNT Libraries and librarians who are interested in promotion preparedness mentoring. Table 1 provides the demographics of the participants of the program during its first three years (FY 2015/16 through FY 2017/18). The Mentoring Program includes mentor-protégé dyads, group mentoring, and mentor training. Protégés may participate in more than one component of the program, depending on their interests.

[Place Table 1 here.]

Mentors and protégés are matched by the Mentoring Program Workgroup. The mentorship coordinator meets with new librarians and their supervisors to discuss participation in the program. Protégés are asked to complete a questionnaire with information about their research interests and the areas in which they would like to be mentored. Likewise, potential mentors are asked to complete a questionnaire with information about their research interests and the areas in which they can provide mentoring. The mentorship coordinator then reviews the survey responses and makes recommendations for mentoring partnerships. Each participant is asked for their consent on the proposed partnership before it is finalized. The mentorship coordinator periodically contacts the participants individually to ask for feedback on the mentoring partnerships and to determine if any reassignments are needed. The formal requirements for the mentor-protégé dyads are minimal in order to provide flexibility for the partnerships. Each pair is 
expected to meet monthly. They also are expected to develop and agree to a formal document of mentoring expectations.

The composition and emphasis of the mentoring groups vary each year according to the needs of the participants. Mentoring groups have focused on providing support to new librarians, educating librarians in research methods, and preparing librarians to apply for promotion. Each mentoring group is led by an experienced senior librarian. Topics covered by the mentoring groups are provided in Appendix 1.

Mentor training sessions are held to familiarize mentors with their roles and responsibilities. Experienced senior librarians have led the training using a variety of resources, including Building Effective Mentoring Partnerships (Caddick, 2009).

The Mentoring Program Workgroup administers a continuous cycle of assessment with multiple measures and methods. Assessment measures address the goals of the mentoring program, which include facilitating the professional development of protégés, improving mentoring competencies, increasing confidence of participants, and expanding future participation in the program. The assessment instruments include the Mentoring Competencies Assessment, the Fear of Negative Evaluation survey, and the End of Program Evaluation. The Workgroup also has conducted a focus group composed of protégés in the program. All assessments used by the Mentoring Program Workgroup have been approved by the University of North Texas Institutional Review Board.

\section{Assessments and Results}

Mentoring Competencies Assessment (MCA)

As part of the Library's efforts to cultivate a culture of assessment, the Mentoring Program Workgroup sought out valid and reliable methods for assessing the program's impact on the 
development of both protégés and mentors. The authors could find only a few case studies that evaluated mentorship programs in libraries, and these were limited to satisfaction surveys (Cirasella \& Smale, 2011; Colley \& Thorson, 1990; Sapon-White et al., 2004). They therefore looked outside the narrow field of librarianship and discovered more evaluation resources in other disciplines.

Medical researchers developed the Mentoring Competencies Assessment (MCA) to assess a multi-institutional program, the Clinical and Translational Science Awards (CTSA) Mentor Working Group (Fleming et al., 2013). This program supported the training of mentors of young clinical researchers at 16 participating sites using a standard workshop curriculum and training manual. The program facilitators developed an instrument to measure the effect of the training on the mentors' skills, as perceived by the mentors themselves, as well as by their protégés.

The instrument was developed in three phases based on an extensive literature review, alignment with the training curriculum and manual, and cognitive interviews to assess the cognitive validity of the instrument. The final version of the assessment instrument consisted of 26 items on a seven-point Likert-type scale asking the mentors to assess their own skills (MCA for Mentors), and for mentees to assess the skills of their mentors (MCA for Protégés). The items covered six categories of competencies:

- maintaining effective communication,

- aligning expectations,

- assessing understanding,

- fostering independence,

- $\quad$ addressing diversity, and

- promoting professional development. 
The MCA was subjected to rigorous testing of reliability and construct validity, and it was found to be moderately reliable and have strong construct validity (Fleming et al., 2013). In the validation study, the mentors and the protégés took the assessment prior to the training, which was provided some time after the mentorship program had begun. The sample tested included 283 mentors and 283 protégés from 16 different institutions. The developers described the results aggregated by group. They tested reliability using the alpha coefficient method for each group (mentors and protégés separately). They tested the construct validity of the competencies using confirmatory factor analysis, calculating maximum likelihood estimates.

The developers found that the mentors consistently rated their own competencies lower than the protégés rated their mentors. They found that the coefficient alpha scores for all responses in each group were quite high (.91 and .95 , with 1.00 representing perfect reliability). There were variations in reliability scores by competency category, with ranges from as low as .59 to as high as .91 for each category/participant group. The authors noted that those categories with the lowest reliability had the fewest questionnaire items.

The MCA developers found that the instrument supported their hypothesized model of the relationship of the constructs. The responses in the different categories were moderately or highly correlated; however, they were distinct enough to show a good fit with the data. The developers recommended that the instrument be used by both mentor and protégé as both a diagnostic tool (to assess training needs), as well as an instrument for the assessment of training.

While applications appear to be focused largely in the clinical fields (Johnson \& Gandhi, 2015; Padek et al., 2018; Pfund et al., 2014; Schriver, Cubaka, Vedsted, Besigye, \& Kallestrup, 2018; Spencer et al., 2018), the MCA has been used to assess mentoring programs in broader academic fields (Daniels et al., 2016; Mickel, Wiskur, James, VanWagoner, \& Williams, 2018; 
Weigel, 2015). The MCA is freely available from the University of Wisconsin (University of Wisconsin Institute for Clinical and Translational Research, 2019).

Because the MCA tool was rigorously tested and validated using standard psychometric methods, the Mentoring Program Workgroup selected it to assess the impact of training and support provided to the mentors throughout the year. The items in the survey are considered general enough to apply to the librarianship environment, despite it being developed for a clinical research training program. One item from the original MCA survey was removed, because it was related to setting research goals, which was not considered a priority for the new librarians.

The authors modified the MCA for Protégés in one more notable way. Because the authors wanted to assess the impact of training and experience on the mentor's competencies, they implemented a pre- and post-test method for the MCA. The mentors would complete the MCA for Mentors at the beginning of the program year, before the initial training. Protégés would similarly complete a pre-test version of the MCA for Protégés, for which they were asked to rate the importance of each competency. At the end of the year, the protégés would complete the post-test version of the MCA for Protégés, which asks them to rate their mentor's competencies. Similarly, the mentors would complete the MCA for Mentors, asking them to rate themselves on each competency. The importance values of the competencies enabled the Mentoring Program Workgroup not only to put the mentors' competencies into context of the protégés' importance values, but also to prioritize the competencies to build.

The same assessment measures were used for each of the three years of the Mentoring Program at the UNT Libraries, from FY 2015/16 through FY 2017/18. All participants in these three years were professional librarians. Most of the protégés were new to academic 
librarianship, while the mentors had extensive experience in their specializations, in academic librarianship in general, and at the university library, specifically. Mentors and protégés responded to the assessments in each year. Some individuals participated in the program during multiple years and responded to assessments in each of these years.

The MCA results discussed in this assessment are accumulated from three consecutive annual mentoring programs. The authors calculated the mean and standard deviation, median, and mode for each of 25 items ranked by mentors and protégés to measure mentors' competency levels. The authors also compared the ratings from the surveys taken at the beginning of the program (pre-test) with those taken at the end of the program (post-test). Because the surveys were sent anonymously, these analyses could be conducted only at the group level and not at the individual participant level.

The mean scores for the skills assessed on the pre-test version of the MCA for Mentors, as rated by the mentors themselves, are between 4.75 and 5.85, with the lowest score for "Setting clear mentoring relationship expectations" and the highest score for "Acknowledging protégé's professional contribution" (Table 2). At the end of the mentoring program year, the range of the scores for the post-test version of the MCA for Mentors actually increased to 3.18-6.18, with the lowest score for "Coordinating effectively with supervisor(s)," and the highest score for "Establishing a trustful relationship." The mean score and standard deviation of mentors' ratings of most skills were higher in post-test, compared to their ratings in pre-test. [Place Table 2 here.]

The range of mean scores for the importance of the skills, as rated by the protégés in the pre-test version of the MCA for Protégés, ranged between 5.28 and 6.56, with the lowest score for "Helping protégé maintain work-life balance" and highest scores for "Developing strategies 
to achieve goals" (Table 3). As with the MCA for Mentors, the range of mean scores increased to 5.55-6.8 in the post-test.

[Place Table 3 here.]

The mentors' ratings of their own skills, with only few exceptions, were consistently lower than the protégés' importance of the mentors' skills and the protégé's assessments of these skills. For example, mentors' self-reported score post-test was higher than 6.0 for only two competencies ("Establishing a trustful relationship" and "Acknowledging protégé's professional contribution"), while mean scores of protégés' assessment of mentors' skills were higher than 6.0 in eleven items. Both groups gave the highest post-test ratings to the "Establishing a trustful relationship" skill.

\section{Fear of Negative Evaluation (FNE)}

Several studies indicate that social anxieties and impostor syndrome result in lower levels of confidence and self-esteem, which may affect one's professional performance (Dancy \& Brown, 2011; Carleton, Collimore, \& Asmundson, 2007; Thompson, Kaminska, Marshall, \& Zalk, 2019). Because one of the goals of the Mentoring Program is to increase the confidence of earlycareer librarians, the authors were interested in assessing the success of the program's efforts by measuring librarians' Fear of Negative Evaluation.

Watson and Friend (1969) identified three social-evaluative anxieties and developed two scales to measure them. A Social Avoidance and Distress (SAD) scale was designed to measure two social-evaluative anxieties: "experience of distress, discomfort, fear, anxiety, etc. in social situations" and "deliberate avoidance of social situations." Watson and Friend also created a Fear of Negative Evaluation (FNE) scale to measure the "fear of receiving negative evaluations from others" (p. 448). Both of these scales have been used widely in different studies ever since. The 
authors defined FNE as 'apprehension about others' evaluations, distress over their negative evaluations, avoidance of evaluative situations, and the expectations that others would evaluate oneself negatively" (p. 449).

Watson and Friend (1969) crafted the questions to capture the targeted trait, "fear of loss of social approval," (p. 449) and its opposite, lack of anxiety about the evaluations of others, and not the presence of other traits such as the desire for positive evaluation. The authors cite the validity and homogeneity of the FNE scale in their article. The FNE scale contains 30 true/false items or statements, of which 17 are scored if answered as true and 13 are scored if answered as false. The scores range from 0 to 30 , with higher scores indicating greater fear. Those who score high on the FNE scale try to avoid negative evaluation, therefore, they work harder on a dull task comparing to those who score low on the FNE. High FNEs express that they feel worse when receiving negative evaluations and they tend to be more socially anxious (Leary, 1983).

There have been some complaints about the length of the FNE scale. To address this issue and increase the usability of the FNE, Leary developed a brief version in 1983. The brief FNE (BFNE) contains only 12 items on a five-point Likert scale and correlates very highly with the original FNE (Leary, 1983).

The Mentoring Program Workgroup considered using the FNE scale, among other anxiety assessments, because librarians were shown to suffer from FNE in a 2015 study by Crawford et al. The participants in the study reported through open-ended questions that FNE made them hesitant to take advantage of advancement opportunities. The Workgroup decided to use only the FNE to assess the protégé participants because it is best suited for measuring effects of anxiety in evaluative situations while SAD scale measures social distress and avoidance of social situations. The results would also indicate whether the program was lowering the FNE barrier to public 
speaking, making presentations, submitting manuscripts, serving in leadership positions, and seeking promotion and other advancements among the protégés.

The Mentoring Program Workgroup administered the original version of FNE survey to the protégés at the beginning and end of each year of the Mentoring Program. The researchers scored the responses according to the key found in the Watson and Friend article (1969). Responses which were indicative of the construct, fear of negative evaluation, were given one point. The cumulative sum of the points indicated each participant's FNE score. The data were analyzed to find the mean, median, and mode among all participants for pre- and post-tests (Table 4).

The mean score for all pre-tests was 16.35 with a median of 15.50 . This was consistent with the mean of 16.72 among the 403 librarians assessed in the Crawford et al. study (2015). The mean for all the post-tests was 15.60 with a median of 16.00 (Table 4). This represents a decrease of 0.75 points, or $4.6 \%$ in the mean score.

[Place Table 4 here.]

\section{Satisfaction Survey (End of Program Evaluation)}

In addition to the MCA and FNE tools, the Mentoring Program Workgroup implemented the End of Program Evaluation survey to gauge participant satisfaction and collect feedback on areas of improvement and suggestions for future program years. Rather than design a new evaluative survey, the Workgroup adapted the End of Program Evaluation created by the Administrative Professional Mentoring Program at the University of Illinois at Chicago (UIC). It was developed for a mentoring program that supported new clinical researchers. (NOTE: The survey is no longer available online, but the authors of this article printed a copy, which is available upon request.) 
The Mentoring Program administrators modified some of the questions in the original survey to better fit the local program's structure and terminology. The original tool consisted of 26 questions: 22 Likert-scaled and four essay. They additionally added entries for participants to comment on the program's structure and their individual mentoring relationships. The final tool consisted of a total of 28 questions: 22 Likert-scaled and six essay. Of the Likert-scaled questions, 10 focused on the features of the program, 10 on individual mentoring relationships, and two on the overall program experience. Participants responded on a five-option Likert scale ranging from "Strongly agree" to "Strongly disagree" for the program; an eight-option Likert scale for the relationship ranging from "Strongly agree" to "Strongly disagree," including a "not applicable" option, and a four-option scale for the overall program experience. The other six open-ended questions allowed for commentary on the scaled questions and inclusion of specific details about the mentoring relationship and experience.

Although no documentation of validity testing could be found, its absence is not unusual in a formative evaluation. Payne (1994) describes Scriven's idea of two types of evaluation, summative and formative, and the different aspects that distinguish them. A summative evaluation uses "absolute or comparative standards and judgement" to describe the worth and value of something, and it is often used to certify a program (p. 8). Conversely, Payne explains a formative evaluation is used to improve an educational experience or product during its developmental stage. Summative evaluations often use valid/reliable measures, while formative are more often informal. Given the young nature of the program, as well as the availability of the UIC's survey for reproduction, the Workgroup believed the End of Program Evaluation would be a useful tool for improving the program in the future. 
The Mentoring Program Workgroup distributed End of Program Evaluation surveys at the Year-End Celebration during each of the first three years of the program. The results of the survey discussed are accumulated from two consecutive annual mentoring programs, FY 2016/17 and FY 2017/18. The results of the survey for the FY2015/16 cohort were not included in this report because of changes made to the survey instrument.

The Mentoring Program Workgroup determined the mean, median, and mode for each of the questions answered by the mentors and protégés (as displayed in Table 5). The mean satisfaction of the program ranged from 1.21 to 1.74 on a scale of "Strongly agree" $=1$ and "Strongly disagree" $=5$. The highest responses were collected for "I would recommend the mentoring program to others" and the lowest for "The overall expected outcomes for the mentoring program were realistic.”

The mean satisfaction of the mentoring relationships ranged from 1.75 to 2.90 on a scale of "Strongly agree" =1 and "Strongly disagree" =7 (Table 5). The highest responses were collected for "My mentor/protégé understood what I was saying and we had meaningful conversations" and the lowest for "My protégé shared concerns and asked good questions." The mean satisfaction scores for the program's overall experience was 1.29 on a scale of "Extremely satisfied" = 1 and "Somewhat dissatisfied" = 4. The mean effectiveness score was 1.71 on a scale of "Very effective" $=1$ and "Not effective at all" $=4$.

\section{Focus group}

The Mentoring Program Workgroup decided, after three years of evaluating the mentoring program through the MCA, FNE and satisfaction surveys, that conducting a qualitative assessment would enrich the data gathered from mentors and mentees. Qualitative methods offset the limitations of surveys, some of which are the inability to describe the nature of 
subjects' development over time or capture the social context of responses (Clark \& Ivankova, 2016). The Workgroup selected the focus group method to assess whether the program was meeting its goals. In addition to gathering a fuller picture of professional development of the participants, this method has the advantages of creating a group interaction in which ideas emerge that might be absent in individual interviews (Liamputtong, 2011c) and getting feedback from multiple participants during one event.

The Mentoring Program Workgroup concentrated on the protégés in the library's program for the focus group conducted in August 2018. It was the first focus group the Workgroup had conducted; therefore, the group wanted to learn the method and improve the approach before assessing the protégées. The study population consisted of librarians who had completed two years in the mentoring program and had experienced both dyad and group mentoring. The Workgroup selected these criteria to assess subjects with enough experience in the program to discuss their development over time, and to gather their insights on both the dyad and group mentoring. Twelve librarians fit the criteria for the study population, but two who are members of the Workgroup were excluded for lack of impartiality. The final study population included 10 potential subjects.

The Mentoring Program Workgroup made anonymity of the subjects a priority throughout the implementation of the protégé focus group in order to encourage free discussion of the program. While none of the Workgroup members were supervisors of the protégés, the Workgroup did not want the protégés to curtail their responses from any fear of negative impacts. The UNT IRB approved the study, with special measures to protect the anonymity of the participants. The Workgroup enlisted the help of a graduate student employed by the library, who had experience in conducting focus groups. He became the sole contact for the subjects 
throughout the process. The student sent an invitation email to the 10 librarians, and assigned random numbers to the five who agreed to participate. The numbers were used to identify the subjects from that point forward.

The focus group arrangements all worked toward making an environment where the protégés would feel comfortable sharing their honest opinions of the Mentoring Program. The Workgroup asked an education professor experienced in qualitative assessment, who did not know any of the participants, to be the facilitator for the focus group. The conference room scheduled for the focus group was located in an academic building out of sight of the library. The setup time for the conference room and the arrival time of the participants were staggered to prevent the researchers from seeing the participants. The facilitator asked prepared questions written by the researchers, which were formulated along guidelines from Liamputtong (2011a). The graduate student took notes during the two-hour discussion, identifying the speakers by their random number assignments, and made an audio recording of the event. During the focus group, the facilitator asked an additional follow-up question, which is listed with the prepared questions in Appendix 2.

The analysis of the focus group responses started with the transcription of the notes and audio recording. The graduate student transcribed the audio recording verbatim and included pauses, exclamations, laughter, and other expressions that lend context to the text (Liamputtong, 2011b). Three of the authors conducted a thematic analysis of the transcription, as described by Liamputtong. Initially all three read the transcription and identified themes. Then these common themes were used by one author to code the subjects' discussion in NVivo 12:

- benefits and drawbacks of the mentoring program,

- broader perspective on the library organization and its activities, 
- opportunities for networking,

- preparation for promotion,

- development of career trajectory, and

- support and sense of belonging.

The focus group's discussion suggests that the program is progressing towards meeting its goals and needs improvements. One of the program's goals is to increase the confidence of the protégés. The junior librarians have appreciated mentors who outline the steps needed to advance from a new librarian to one ready for promotion. Mentors also clarified the actual promotion application process and the types of documentation that should be in a dossier. Through group mentoring, the protégés were able to meet members of the Personnel Affairs Committee and get feedback on their curriculum vitae. All of these activities have made the protégés more confident about what they need to accomplish for their first promotion to Associate Librarian.

Another goal of the Mentoring Program is to improve mentoring competencies. According to the protégés, their mentors and peers have strong psychosocial skills. The protégés mentioned repeatedly that they value the confidentiality provided to them both through the dyad and group mentoring. The mentors and peers are good listeners with whom they can discuss work and professional concerns without being judged or labeled as having a bad attitude. All of the protégés expressed a sense of belonging because their mentors and peers have shared their own struggles with feelings of inadequacy and with finding suitable solutions to career problems.

While performing well in psychosocial competencies, the protégés' comments suggest the mentors need to improve in the areas of creating and aligning expectations and guiding professional development. Most of the protégés in this focus group had experienced a more informal relationship with their mentors, with few structured activities and objectives for 
professional development beyond promotion preparation. It was clear to the protégés who participated in the first year of the program that the mentors were still in training.

The protégés had helpful suggestions to improve the group mentoring, which they value for coordinated activities and camaraderie. They recommended making the names of the mentoring groups match their purposes. UNT's mascot is the eagle and the incorporation of eagle references in names muddied the intent of the groups. The protégés also favored having the group mentoring in cohorts, rather than changing the group composition every year, in order to maintain an environment where they feel comfortable sharing accomplishments and concerns.

Overall, the protégés are pleased with the Mentoring Program and want to see it continue. They mentioned multiple times that the program gives them a broader perspective of the library organization and of librarianship, showing them different solutions to work challenges and a variety of career opportunities. The protégés all agreed the library administration should sustain the program with funding. Finally, they were also in agreement they would all like to serve as mentors in the future based on their positive experiences.

\section{Discussion and conclusion}

The goals of the initial programs were to develop the professional skills of the new librarians, increase the confidence of early-career librarians, and improve the mentoring skills of the established librarians. The authors included assessment of these goals from the initial pilot of the program in FY 2015/16 using the three surveys described above. These surveys, developed from outside of the field of librarianship, were selected largely because there were so few options available from within the field of librarianship. Most reports of mentoring programs in library literature did not include any assessment at all. Of those that did, the primary method was satisfaction surveys, which were not tested for validity. 
While the library is considered a mid-sized academic library, the number of individuals participating each year would be limited. Thus, the authors established a model of continuous assessment that could be used over the long term. Accumulating responses over the years of the program will enable the Mentoring Program Workgroup to have more statistically valid analyses of effectiveness. With these regular assessments, the Workgroup will be able to plan new programs and make improvements.

After two years of assessment, it became apparent that quantitative measures of assessment alone had not provided enough information to improve the program. The Workgroup wanted to learn more about how the participants felt about the program, their impressions of one-on-one mentoring, and their viewpoints of the quality of the program. Towards that end, the Mentor Program Workgroup pursued a qualitative method by conducting a focus group. To reduce bias and protect anonymity, the authors took extraordinary efforts by having a moderator from outside the library and conducting the focus group session in a separate building.

The results of the focus group support the results of the three surveys given to mentors and protégés. All protégés in the focus group agreed that their mentors and peers had been successful in creating a trustful environment by providing confidentiality and strong listening skills, which supports the post-test MCA for Mentors, who rated themselves highest on the skill, "Establishing a trustful relationship." The protégés' comments were also consistent with the lowest mean score in the End of Program Evaluation, "My mentor offered guidance and knowledge." The protégés commented that the mentors were helpful with their preparations for promotion, but they needed more structured guidance for overall career planning. The confidence of the protégés increased regarding their upcoming promotion applications, which aligns with the decrease in the post-test score of the FNE. 
Through these assessments, the Mentoring Program Workgroup has documented measures of success in meeting the goals of preparing new librarians for academic librarianship and the rigors of promotion. Their self-confidence has improved, as documented by the reduced scores of the FNE scale, as well as by their responses to the open-ended questions of the End of Program Evaluation survey, as well as within the focus group. While there is documented improvement in the mentors' self-assessment of skills through the MCA scores, the responses to the open-ended questions and the focus group responses indicate that more effort is needed to improve mentorship skills.

There are a few limitations of the Mentoring Program Workgroup's assessment methods, notably the difficulty of improving response rates, the inability to analyze results at the individual- and dyad-levels, and the lack of a measure of ultimate impact on the protégés. The response rates have only been modest since the first year, even with incentives. The Workgroup has received approval to use additional small-scale incentives, funded by the program's FY 2018/19 budget, and will also include time in the annual celebratory event for the participants to submit their end-of-program surveys on site. The Mentoring Program Workgroup will track response rates to determine the value of these measures.

In the first year, there was an attempt to track individual pre- and post-program responses to the MCA while maintaining anonymity, whereby participants were asked to input the last four digits of their phone number. This method was not successful because the Workgroup did not make it mandatory, and some entered different numbers in the pre- and post-tests. For later iterations, the surveys were sent anonymously without any tracking capability. While this method eased survey distribution, it did not enable the Workgroup to analyze results beyond the group level. The Mentoring Program Workgroup has since received the university's Institutional 
Review Board approval to change the survey from anonymous to confidential, enabling future analyses at group, individual, and dyad levels.

The most important limitation, however, is that the above assessments do not measure the ultimate goal of the program, which is for the librarians who participate to be successful in their careers. While increasing self-confidence is a step towards that, the Workgroup currently has no other valid measure associated with this goal. Such an outcome is difficult to measure because the meaning of "successful in their careers" is ambiguous, there are many factors that contribute to such an outcome, and there is a long period of time after the end of the formal program before such results would be measurable. With these difficulties in mind, the Mentoring Program Workgroup will be reviewing optimal measures, including, but not limited to, time to promotion, annual evaluation scores, participation in other career development activities, and overall career satisfaction.

The authors believe that these methods provide a good foundation for evaluating mentoring programs, not only the unique program described in this article, but also similar programs at other libraries. The Mentoring Program Workgroup will continue to collect data using these tools for longitudinal analysis of the impacts of mentoring on new librarians' confidence and overall career pathways. This addresses Boeren et al.'s recommendation of more longitudinal studies of effectiveness of mentoring programs in higher education (2015). The publication of this article, in which the authors have detailed the methods of evaluation, including links to actual surveys, addresses another limitation of this field that was found in the literature review. Finally, the authors believe the combination of the use of validated quantitative surveys and rigorous qualitative methods fills a gap in methods used to evaluate mentoring programs. 
Appendix 1: Topics Covered by Mentoring Groups

New Librarians' Mentoring Group

Preparing documentation for the annual evaluation cycle

Communicating with one's supervisor

Personality tests and their application in the workplace

Productive writing strategies

Professional service opportunities

Work life balance

Time management

Professional conferences

Developing a scholarly identity

\section{Research Mentoring Group}

Quantitative research methods

Qualitative research methods

Descriptive statistics

Inferential statistics

Preparation for Promotion Mentoring Group

Review of promotion requirements

Review of the work of successful promotion applicants

Review of the work of the mentoring group members

Consultations with members of the Personnel Affairs Committee 
Development of plans to address gaps in preparation for promotion

Finding service opportunities

Reviewing curricula vitae

Organizing the documentation required for a promotion application

Preparing the application for promotion

Writing the promotion application essay

Selecting references 


\section{Appendix 2: Questions for the Protégé Focus Group}

Introduction: Would you tell me about one highlight of your experience in the mentoring program?

Transition: How did you interact with your mentor?

Focus: How has the one-on-one mentoring influenced your job and development as a professional librarian?

Focus: How has the group mentoring influenced your job and development as a professional librarian?

Focus: How has the mentoring program impacted your attitude towards your job and librarianship in general?

- Follow up if needed: How has your confidence level in performing your job and contributing to your profession changed?

- *Follow up if needed: How has the program affected your sense of belonging in the UNT Libraries and professional communities?

Focus: How could the mentoring program be improved to increase participation of new librarians in the future?

Focus: What have you valued the most in your experience in the mentoring program?

**Concluding: Would any of you consider being a mentor in this program if you have the opportunity? If so, why would you choose to mentor?

Concluding: Is there anything else you think we should discuss about the mentoring program, but haven't?

*The facilitator did not ask this question because it had already been answered.

**The facilitator added this question. 


\section{Bibliographical references}

Anaya, T., \& Maxey-Harris, C. (2017). SPEC kit 356: Diversity and inclusion. Washington, D.C.: Association of Research Libraries. Retrieved from https://statistical.proquest.com/statisticalinsight/result/pqpresultpage.previewtitle?d ocType=PQSI\&titleUri=/content/2017/A3365-14.83.xml

Bean, N. M., Lucas, L., \& Hyers, L. L. (2014). Mentoring in higher education should be the norm to assure success: Lessons learned from the faculty mentoring program, West Chester University, 2008-2011. Mentoring \& Tutoring: Partnership in Learning, 22(1), 56-73. doi:10.1080/13611267.2014.882606

Bell, A., \& Treleaven, L. (2011). Looking for professor right: Mentee selection of mentors in a formal mentoring program. Higher Education, 61(5), 545-561. doi:10.1007/s10734-010$9348-0$

Bertram, A., Yeh, H. C., Bass, E. B., Brancati, F., Levine, D., \& Cofrancesco, J. (2015). How we developed the GIM clinician-educator mentoring and scholarship program to assist faculty with promotion and scholarly work. Medical Teacher, 37(2), 131-135. doi:10.3109/0142159X.2014.911269

Bland, C. J., Taylor, A. L., Shollen, S. L., Weber-Main, A. M., \& Mulcahy, P. A. (2011). Faculty success through mentoring: A guide for mentors, mentees, and leaders (Paperback ed.). Lanham, MD: Rowman \& Littlefield.

Boeren, E., Lokhtinak-Antoniou, I., Sakurai, Y., Herman, C., \& McAlpine, L. (2015). Mentoring: A review of early career researcher studies. Frontline Learning Research, 3(3), 68-80. doi:10.14786/flr.v3i3.186 
Bosch, E. K., Ramachandran, H., Luévano, S., \& Wakiji, E. (2010). The resource team model: An innovative mentoring program for academic librarians. New Review of Academic Librarianship, 16(1), 57-74. doi:10.1080/13614530903584305

Browning, L., Thompson, K., \& Dawson, D. (2014). Developing future research leaders. International Journal for Researcher Development, 5(2), 123-134. doi:10.1108/IJRD-08-2014-0019

Caddick, P. (2009). Building effective mentoring partnerships. Retrieved from http://www.pcaddick.com

Carleton, R. N., Collimore, K. C., \& Asmundson, G. J. G. (2007). Social anxiety and fear of negative evaluation: Construct validity of the BFNE-II. Journal of Anxiety Disorders, 21, 131-141. doi: 10.1016/j.janxdis.2006.03.010

Carney, M. A., Ng, L. E., \& Cooper, T. (2016). Professional development amid change: Fostering academic excellence and faculty productivity at teaching-intensive universities. Journal of Faculty Development, 30(2), 27-35. Retrieved from https://www.ingentaconnect.com/content/nfp/jfd/2016/00000030/00000002/art000 04\%3bjsessionid=2nq58gpa569j.x-ic-live-02\#

Cirasella, J., \& Smale, M. A. (2011). Peers don't let peers perish: Encouraging research and scholarship among junior library faculty. Collaborative Librarianship, 3(2), 98-109. Retrieved from https://digitalcommons.du.edu/collaborativelibrarianship/vol3/iss2/5/

Clark, V., \& Ivankova, N. (2016). Why use mixed methods research? Identifying rationales for mixing methods. Mixed methods research: A guide to the field (pp. 79-104). Thousand Oaks, California: SAGE Publications, Inc. doi:10.4135/9781483398341 
Cofrancesco, J., Barone, M. A., Serwint, J. R., Goldstein, M., Westman, M., \& Lipsett, P. A. (2018). Development and implementation of a school-wide institute for excellence in education to enable educational scholarship by medical school faculty. Teaching \& Learning in Medicine, 30(1), 103-111. doi:10.1080/10401334.2017.1325741

Colley, J., \& Thorson, C. C. (1990, April 1). Mentoring along the tenure track. College and Research Libraries News, 51, 297.

Crawford, L., Leuzinger, J., Brannon, S., \& Hamner, J. (2015). Fear of negative evaluation: Differences amongst librarians. Library Leadership \& Management, 29(3). Retrieved from: https://digital.library.unt.edu/ark:/67531/metadc505019/

Dancy, T. E., II, \& Brown, M. C., II. (2011). The mentoring and induction of educators of color: Addressing the impostor syndrome in academe. Journal of School Leadership, 21(4), 607-634. doi:10.1177/105268461102100405

Daniels, H., Grineski, S. E., Collins, T. W., Morales, D. X., Morera, O., \& Echegoyen, L. (2016). Factors influencing student gains from undergraduate research experiences at a Hispanicserving institution. CBE-Life Sciences Education, 15(3), ar30. doi:10.1187/cbe.15-070163

Farmer, D., Stockham, M., \& Trussell, A. (2009). Revitalizing a mentoring program for academic librarians. College \& Research Libraries, 70(1), 8. doi:10.5860.0700008

Fleming, M., House, S., Hanson, V. S., Yu, L., Garbutt, J., McGee, R., \& Rubio, D. M. (2013). The mentoring competency assessment: Validation of a new instrument to evaluate skills of research mentors. Academic Medicine, 88(7), 1002-1008.

doi:10.1097/ACM.0b013e318295e298 
Fountain, J., \& Newcomer, K. E. (2016). Developing and sustaining effective faculty mentoring programs. Journal of Public Affairs Education, 22(4), 483-506.

doi:10.1080/15236803.2016.12002262

Fox, L. (2012). A personalized faculty peer support program: Less can be more. The Journal of Faculty Development, 26(2), 55.

Fowler, F. (2009). Designing questions to be good measures. Survey research methods (4th ed., pp. 86-113). Thousand Oaks, California: SAGE Publications, Inc. doi:10.4135/9781452230184

Ghouse, N., \& Church-Duran, J. (2008). And mentoring for all: The KU Libraries' experience. portal: Libraries and the Academy, 8(4), 373-386. doi:10.1353/pla.0.0022

Goodsett, M., \& Walsh, A. (2015). Building a strong foundation: Mentoring programs for novice tenure-track librarians in academic libraries. College \& Research Libraries, 76(7), 914933. doi:10.5860/crl.76.7.914

Harker, K. R., O'Toole, E., \& Sassen, C. (2018). Assessing an academic library professional development program. portal: Libraries and the Academy, 18(1), 199-223. doi:10.1353/pla.2018.0010

Harrington, M. R., \& Marshall, E. (2014). Analyses of mentoring expectations, activities, and support in Canadian academic libraries. College \& Research Libraries, 75(6), 763-790. doi:10.5860/crl.75.6.763

Hines, S. R. (2009). Investigating faculty development program assessment practices: What's being done and how can it be improved? The Journal of Faculty Development, 23(3), 519. 
Hubball, H., Clarke, A., \& Poole, G. (2010). Ten-year reflections on mentoring SoTL research in a research-intensive university. International Journal for Academic Development, 15(2), 117-129.

Huenneke, L., Stearns, D., Martinez, J., \& Laurila, K. (2017). Key strategies for building research capacity of university faculty members. Innovative Higher Education, 42(5), 421-435. doi:10.1007/s10755-017-9394-y

Idoko, N. A., Ugwuanyi, R. N. C., \& Osadebe, N. E. (2016). Mentoring: A strategy for professional development of librarians in Nigerian universities. Library Philosophy and Practice, Winter. Retrieved from https://digitalcommons.unl.edu/libphilprac/1360/

Johnson, M.O., \& Gandhi, M. (2015). A mentor training program improves mentoring competency for researchers working with early-career investigators from underrepresented backgrounds. Advances in Health Sciences Education 20(3), 683-689. doi.org/10.1007/s10459-014-9555-z

Johnson, W. B. (2016). On being a mentor: A guide for higher education faculty (Second ed.). New York: Routledge.

Kennedy, M. R., \& Brancolini, K. R. (2018). Academic librarian research: An update to a survey of attitudes, involvement, and perceived capabilities. College \& Research Libraries, 79(6), 822-851. doi:10.5860/crl.79.6.822

Kuyper-Rushing, L. (2001). A formal mentoring program in a university library: Components of a successful experiment. The Journal of Academic Librarianship, 27(6), 440-446. doi:10.1016/S0099-1333(01)00258-0

Law, A. V., Bottenberg, M. M., Brozick, A. H., Currie, J. D., DiVall, M. V., Haines, S. T., . . Yablonskim, E. (2014). A checklist for the development of faculty mentorship 
programs. American Journal of Pharmaceutical Education, 78(5), 1-10.

doi:10.5688/ajpe78598

Leary, M. R. (1983). A brief version of the Fear of Negative Evaluation Scale. Personality and Social Psychology Bulletin, 9, 371-376. doi:10.1177/0146167283093007

Liamputtong, P. (2011a). Conducting focus groups and practicalities. Focus group methodology: Principles and practice (pp. 71-86). London: SAGE Publications Ltd. doi:10.4135/9781473957657.n5

Liamputtong, P. (2011b). Managing and making sense of focus group data. Focus group methodology: Principles and practice (pp. 165-181). London: SAGE Publications Ltd. doi:10.4135/9781473957657.n10

Liamputtong, P. (2011c). Theory and ethics. Focus group methodology: Principles and practice (pp. 15-30). London: SAGE Publications. doi:10.4135/9781473957657.n2

Lorenzetti, D.L., \& Powelson, S.E. (2015). A scoping review of mentoring programs for academic librarians. Journal of Academic Librarianship, 41(2), 186-196. doi:10.1016/j.acalib.2014.12.001

Lunsford, L. G. (2016). A handbook for managing mentoring programs: Starting, supporting and sustaining effective mentoring. London: Routledge.

Marcellino, P. A. (2011). Fostering sustainability: A case study of a pilot mentoring program at a private university. Mentoring \& Tutoring: Partnership in Learning, 19(4), 441-464. doi:10.1080/13611267.2011.622079

Mayer, A. P., Blair, J. E., Ko, M. G., Patel, S. I., \& Files, J. A. (2014). Long-term follow-up of a facilitated peer mentoring program. Medical Teacher, 36(3), 260-266. doi:10.3109/0142159X.2013.858111 
Mickel, N., Wiskur, B., James, J., VanWagoner, T., \& Williams, V. N. (2018). Assessing faculty capacity to build an effective mentoring network at an academic health sciences center. The Journal of Faculty Development, 32(3), 35-46.

Miller, J. P., \& Benefiel, C. R. (1998). Academic librarians and the pursuit of tenure: The support group as a strategy for success. College \& Research Libraries, 59(3), 260-265. doi:10.5860/crl.59.3.260

Minnick, A., Kleinpell, R., \& Norman, L. D. (2018). Promoting faculty scholarship: A clinical faculty scholars program. Journal of Nursing Education, 57(2), 121-125. doi:10.3928/01484834-20180123-11

Morrison, L. J., Lorens, E., Bandiera, G., Liles, W. C., Lee, L., Hyland, R., . . Levinson, W. (2014). Impact of a formal mentoring program on academic promotion of department of medicine faculty: A comparative study. Medical Teacher, 36(7), 608-614. doi:10.3109/0142159X.2014.899683

Nwankwo, T. V., Ike, C. P., \& Anozie, C. O. (2017). Mentoring of young librarians in South East Nigeria for improved research and scholarly publications. Library Management, 38(8/9), 455-476. doi:10.1108/LM-11-2016-0083

Padek, M., Mir, N., Jacob, R. R., Chambers, D. A., Dobbins, M., Emmons, K. M., ... Brownson, R. C. (2018). Training scholars in dissemination and implementation research for cancer prevention and control: a mentored approach. Implementation Science, 13, 1-N.PAG. doi.org/10.1186/s13012-018-0711-3

Payne, D. A. (1994). Designing educational project and program evaluations: A practical overview based on research and experience. Boston: Kluwer Academic Publishers. 
Pfund, C., House, S. C., Asquith, P., Fleming, M. F., Buhr, K. A., Burnham, E. L., ... Sorkness, C. A. (2014). Training mentors of clinical and translational research scholars: A randomized controlled trial. Academic Medicine, 89(5), 774-782. doi:10.1097/ACM.0000000000000218

Sapon-White, R., King, V., \& Christie, A. (2004). Supporting a culture of scholarship for academic librarians. portal: Libraries \& the Academy, 4(3), 407-422. doi:10.1353/pla.2004.0044

Sassen, C., \& Wahl, D. (2014). Fostering research and publication in academic libraries. College \& Research Libraries, 75(4), 458-491. doi:10.5860/crl.75.4.458

Schriver, M., Cubaka, V. K., Vedsted, P., Besigye, I., \& Kallestrup, P. (2018). Development and validation of the ExPRESS instrument for primary health care providers' evaluation of external supervision. Global Health Action, 11(1), 1.

doi:10.1080/16549716.2018.1445466

Sheridan, L., Hubbard Murdoch, N., \& Harder, E. (2015). Assessing mentoring culture: Faculty and staff perceptions, gaps, and strengths. Canadian Journal of Higher Education, 45(4), 423-439. Retrieved from http://journals.sfu.ca/cjhe/index.php/cjhe/article/view/184938

Slimmer, L. (2012). A teaching mentorship program to facilitate excellence in teaching and learning. Journal of Professional Nursing, 28(3), 182-185. doi:10.1016/j.profnurs.2011.11.006

Spencer, K. C., McDaniels, M., Utzerath, E., Rogers, J. G., Sorkness, C. A., Asquith, P., \& Pfund, C. (2018). Building a sustainable national infrastructure to expand research mentor training. CBE-Life Sciences Education, 17(3), ar48. doi:10.1187/cbe.18-03-0034 
Sullivan, D., Leong, J., Yee, A., Giddens, D., \& Phillips, R. (2013). Getting published: Group support for academic librarians. Library Management, 34(8/9), 690-704. doi:10.1108/LM-03-2013-0026

Thomas, J. D., Lunsford, L. G., \& Rodrigues, H. A. (2015). Early career academic staff support: Evaluating mentoring networks. Journal of Higher Education Policy \& Management, 37(3), 320-329. doi:10.1080/1360080X.2015.1034426

Thompson, T., Kaminska, M., Marshall, C., \& Van Zalk, N. (2019). Evaluation of the Social Phobia Scale and Social Interaction Anxiety Scale as assessments of performance and interaction anxiety. Psychiatry Research, 273, 725-731. doi:10.1016/j.psychres.2019.01.103

University of Wisconsin Institute for Clinical and Translational Research. (2019). Mentor evaluation forms examples. Retrieved from https://ictr.wisc.edu/mentoring/mentorevaluation-form-examples/

Varkey, P., Jatoi, A., Williams, A., Mayer, A., Ko, M., Files, J., . . Hayes, S. (2012). The positive impact of a facilitated peer mentoring program on academic skills of women faculty. BMC Medical Education, 12(1), 14. doi:10.1186/1472-6920-12-14

Vilz, A. J., \& Poremski, M. D. (2015). Perceptions of support systems for tenure-track librarians. College \& Undergraduate Libraries, 22(2), 149-166. doi:10.1080/10691316.2014.924845

Watson, D., \& Friend, R. (1969). Measurement of social-evaluative anxiety. Journal of Consulting and Clinical Psychology, 33(4), 448-457.

Weaver, D., Robbie, D., Kokonis, S., \& Miceli, L. (2013). Collaborative scholarship as a means of improving both university teaching practice and research capability. International 
Journal for Academic Development, 18(3), 237-250.

doi:10.1080/1360144X.2012.718993

Weigel, E. G. (2015). Modern graduate student mentors: Evidence-based best practices and special considerations for mentoring undergraduates in ecology and evolution. Ideas in Ecology and Evolution, 8(1), 14-22. doi:10.4033/iee.2015.8.3.c 
Table 1 Demographics of Mentoring Program Participants

FY 2015/16

Protégés Mentors

Total \# of individuals

By Gender ( $f / m)$ 3/2

By minority status* $(y / n) \quad 1 / 4$

* Member of any group that is not white, non-Hispanic, cisgender
FY 2016/17

FY 2017/18

Protégés Mentors Protégés Mentors

$4 \quad 15$

$3 / 1$

$1 / 3$

$10 / 5$

$2 / 13$

14

$12 / 2$

$1 / 13$

11

13

$8 / 5$

$1 / 12$ 
Table 2 Baseline Mean Scores for the 25 Skills Evaluated by the Mentoring Competency Assessment, as Rated by Mentors in FY 2015/16-FY 2017/18

\begin{tabular}{|c|c|c|c|c|c|c|}
\hline \multirow{2}{*}{ Skills by competency } & \multicolumn{3}{|c|}{ Pre-Test $(\mathrm{N}=20)$} & \multicolumn{3}{|c|}{ Post-Test $(\mathrm{N}=17)$} \\
\hline & Mean & Median & SD & Mean & Median & SD \\
\hline \multicolumn{7}{|l|}{ Maintaining effective communication } \\
\hline Active listening & 5.70 & 6 & 0.86 & 5.12 & 5 & 0.73 \\
\hline Providing constructive feedback & 5.40 & 5 & 0.75 & 5.59 & 6 & 0.61 \\
\hline Establishing a trustful relationship & 5.70 & 6 & 0.98 & 6.18 & 6 & 0.41 \\
\hline Identifying and accommodating communication styles & 5.10 & 5 & 0.79 & 5.35 & 6 & 0.81 \\
\hline Applying strategies to improve communication & 4.80 & 5 & 0.89 & 5.06 & 5 & 0.64 \\
\hline Coordinating effectively with supervisor(s) & 5.20 & 6 & 1.11 & 3.18 & 4 & 1.32 \\
\hline \multicolumn{7}{|l|}{ Aligning expectations } \\
\hline Setting clear mentoring relationship expectations & 4.75 & 5 & 1.07 & 5.53 & 6 & 1.03 \\
\hline Aligning expectations & 4.90 & 5 & 0.97 & 5.29 & 5 & 1.14 \\
\hline Considering mentor-protégés differences & 5.20 & 6 & 1.01 & 5.76 & 6 & 1.27 \\
\hline Setting relationship goals & 5.35 & 6 & 1.09 & 5.18 & 6 & 0.89 \\
\hline Developing strategies to achieve goals & 5.40 & 6 & 0.94 & 5.59 & 6 & 0.92 \\
\hline \multicolumn{7}{|l|}{ Assessing understanding } \\
\hline Assessing protégé's knowledge & 5.15 & 6 & 1.14 & 5.35 & 6 & 1.32 \\
\hline Estimating protégé's ability & 5.15 & 5 & 1.27 & 5.12 & 5 & 1.09 \\
\hline Enhancing protégé's knowledge and abilities & 5.35 & 6 & 1.04 & 5.53 & 6 & 1.04 \\
\hline \multicolumn{7}{|l|}{ Fostering independence } \\
\hline Motivating protégé & 4.85 & 5 & 1.14 & 5.06 & 5 & 0.93 \\
\hline Building protégé's confidence & 5.20 & 6 & 1.15 & 5.53 & 6 & 0.83 \\
\hline Stimulating protégé's creativity & 5.05 & 5 & 1.19 & 4.88 & 5 & 1.00 \\
\hline Acknowledging protégé's professional contribution & 5.85 & 6 & 0.93 & 6.12 & 6 & 0.91 \\
\hline Negotiating a path to professional independence & 4.80 & 5 & 1.44 & 5.35 & 5 & 0.79 \\
\hline \multicolumn{7}{|l|}{ Addressing diversity } \\
\hline Accounting for biases and prejudices & 5.15 & 6 & 1.09 & 5.59 & 6 & 1.02 \\
\hline Accounting for mentor-protégé differences & 5.45 & 6 & 1.70 & 5.29 & 6 & 1.30 \\
\hline \multicolumn{7}{|l|}{ Promoting professional development } \\
\hline Helping network effectively & 4.80 & 5 & 1.51 & 5.00 & 5 & 1.15 \\
\hline Helping protégé set career goals & 5.25 & 6 & 1.25 & 5.29 & 5 & 0.91 \\
\hline Helping protégé maintain work-life balance & 5.10 & 6 & 1.41 & 5.24 & 5 & 1.33 \\
\hline Understanding impact as a role model & 4.85 & 5 & 1.39 & 5.41 & 6 & 0.93 \\
\hline
\end{tabular}


Table 3 Baseline Mean Scores for the 25 Skills Evaluated by the Mentoring Competency Assessment, as Rated by Protégés in FY 2015/16-FY 2017/18

\begin{tabular}{|c|c|c|c|c|c|c|}
\hline \multirow{2}{*}{ Skills by competency } & \multicolumn{3}{|c|}{ Pre-Test $(\mathrm{N}=25)$} & \multicolumn{3}{|c|}{ Post-Test $(\mathrm{N}=20)$} \\
\hline & Mean & Median & SD & Mean & Median & SD \\
\hline \multicolumn{7}{|l|}{ Maintaining effective communication } \\
\hline Active listening & 6.20 & 7 & 1.08 & 6.30 & 6 & 0.73 \\
\hline Providing constructive feedback & 6.44 & 7 & 0.71 & 6.50 & 7 & 0.61 \\
\hline Establishing a trustful relationship & 6.48 & 7 & 0.71 & 6.80 & 7 & 0.41 \\
\hline Identifying and accommodating communication styles & 6.00 & 6 & 0.82 & 6.15 & 6 & 0.81 \\
\hline Applying strategies to improve communication & 5.96 & 6 & 0.93 & 6.10 & 6 & 0.64 \\
\hline Coordinating effectively with supervisor(s) & 5.83 & 6 & 1.37 & 5.89 & 7 & 1.32 \\
\hline \multicolumn{7}{|l|}{ Aligning expectations } \\
\hline Setting clear mentoring relationship expectations & 6.24 & 6 & 0.78 & 5.70 & 6 & 1.03 \\
\hline Aligning expectations & 6.04 & 6 & 0.68 & 5.65 & 6 & 1.14 \\
\hline Considering mentor-protégés differences & 5.68 & 6 & 0.99 & 5.65 & 6 & 1.27 \\
\hline Setting relationship goals & 6.16 & 6 & 0.99 & 5.80 & 6 & 0.89 \\
\hline Developing strategies to achieve goals & 6.56 & 7 & 0.71 & 6.00 & 6 & 0.92 \\
\hline \multicolumn{7}{|l|}{ Assessing understanding } \\
\hline Assessing protégé's knowledge & 5.68 & 6 & 1.14 & 5.55 & 6 & 1.32 \\
\hline Estimating protégé's ability & 6.00 & 6 & 1.08 & 5.85 & 6 & 1.09 \\
\hline Enhancing protégé's knowledge and abilities & 6.38 & 7 & 0.88 & 6.15 & 6 & 1.04 \\
\hline \multicolumn{7}{|l|}{ Fostering independence } \\
\hline Motivating protégé & 5.48 & 5 & 1.16 & 5.85 & 6 & 0.93 \\
\hline Building protégé's confidence & 5.68 & 6 & 1.03 & 6.05 & 6 & 0.83 \\
\hline Stimulating protégé's creativity & 6.00 & 6 & 0.91 & 5.95 & 6 & 1.00 \\
\hline Acknowledging protégé's professional contribution & 5.40 & 5 & 1.08 & 6.10 & 6 & 0.91 \\
\hline Negotiating a path to professional independence & 5.92 & 6 & 1.38 & 6.10 & 6 & 0.79 \\
\hline \multicolumn{7}{|l|}{ Addressing diversity } \\
\hline Accounting for biases and prejudices & 5.52 & 6 & 1.00 & 5.58 & 5 & 1.02 \\
\hline Accounting for mentor-protégé differences & 5.48 & 5 & 1.16 & 5.70 & 6 & 1.30 \\
\hline \multicolumn{7}{|l|}{ Promoting professional development } \\
\hline Helping network effectively & 6.16 & 6 & 1.03 & 5.95 & 6 & 1.15 \\
\hline Helping protégé set career goals & 6.12 & 6 & 0.83 & 6.10 & 6 & 0.91 \\
\hline Helping protégé maintain work-life balance & 5.28 & 5 & 1.43 & 5.74 & 6 & 1.33 \\
\hline Understanding impact as a role model & 5.64 & 6 & 1.08 & 5.85 & 6 & 0.93 \\
\hline
\end{tabular}


Table 4 FNE Score Analysis of Protégés in FY 2015/16-FY 2017/18

\begin{tabular}{l|rrr}
\hline & \multicolumn{1}{c}{ Mean } & \multicolumn{1}{c}{ Median } & Mode \\
\hline Pre-Test $(\mathbf{N}=\mathbf{1 0})$ & 16.35 & 15.50 & 19 \\
Post-Test $(\mathbf{N}=\mathbf{1 0})$ & 15.60 & 16.00 & 25 \\
\hline
\end{tabular}


The Mentoring Program (1= Strongly Agree, 5 = Strongly Disagree)

The kick-off event was informative and a beneficial way to start the program.

The goals and objectives of the mentoring program were clearly defined.

The structure of the program made it easy to perform my role in this relationship.

I felt supported by the mentoring committee.

The time commitment for each interaction was just right.

I felt the match between my mentoring partner and I was a good fit.

I believe the program will benefit my professional development.

The overall expected outcomes for the mentoring program were realistic.

Realistic Expectations

I would recommend the mentoring program to others.

Mentoring Relationship (1= Strongly Agree, 7 = Strongly Disagree)

The match between my mentoring partner and I met my needs.

We met regularly.

We came prepared to use the time effectively.

We were confident about what to do when we started.

My mentor/protégé understood what I was saying and we had meaningful conversations.

I experienced learning and growth during the process.

My mentor offered guidance and knowledge.

My protégé shared concerns and asked good questions.

My mentor/protégé enlightened me.

This relationship will continue beyond the formal process.

Overall Experience (1= Extremely satisfied/Very effective, 4 = Somewhat dissatisfied/Not at all effective)

How satisfied were you with your experience as a mentor/protégé?

How effective was the overall program?

\begin{tabular}{l|l|l}
1.29 & 1 & 1 \\
1.71 & 2 & 2 \\
\hline
\end{tabular}

